\title{
Modern Trends in the Field of Solving Transboundary Problems in Groundwater Extraction
}

\author{
Ekaterina Golovina * and Karina Karennik
}

Citation: Golovina, E.; Karennik, K. Modern Trends in the Field of Solving Transboundary Problems in Groundwater Extraction. Resources 2021, 10, 107. https://doi.org/ $10.3390 /$ resources 10100107

\section{Academic Editors: Eleftherios}

I. Thalassinos, Noja Grațiela Georgian and Mirela Cristea

Received: 23 August 2021

Accepted: 13 October 2021

Published: 19 October 2021

Publisher's Note: MDPI stays neutral with regard to jurisdictional claims in published maps and institutional affiliations.

Copyright: (c) 2021 by the authors. Licensee MDPI, Basel, Switzerland. This article is an open access article distributed under the terms and conditions of the Creative Commons Attribution (CC BY) license (https:// creativecommons.org/licenses/by/ $4.0 /)$.
Department of Economics, Organization and Management, Saint-Petersburg Mining University, 2, 21st Line, 199106 Saint-Petersburg, Russia; karinakarennik@gmail.com

* Correspondence: golova2107@mail.ru; Tel.: +7-921-3265-410

\begin{abstract}
The intensive exploitation of water resources negatively affects the ecological situation in many international water objects. The problem of a shortage of drinking water is aggravating, water bodies are subject to pollution by domestic and industrial wastewater, and the water quality in the basins of international water courses continues to deteriorate. This situation primarily requires legal regulation. Until recently, despite a significant number of existing international treaties on the use of transboundary waters, there was no universal international legal act to systematize the basic principles and norms of behavior of the states in this area. The most important direction for improving public administration in the field of use and protection of transboundary groundwater bodies is the development and expansion of international cooperation and the legal consolidation of the rights and obligations of states through the adoption of legislative acts on various levels. Modern international policy in the field of transboundary groundwater resources management is undergoing significant changes. The very concept of a transboundary territory in relation to groundwater extraction was adopted both in Russia and in Europe in the early 2000s. However, the main criteria for the definition of a transboundary territory have not yet been formulated anywhere. This gives rise to the need to define a transboundary aquifer in international legislation, as well as to limit the size of this aquifer. This paper is devoted to the analysis of approaches to the definition of "transboundary aquifer", emerging problems in this area, the legal framework, and conflicts in the field of transboundary regulation of groundwater. The zone of responsibility in groundwater extraction at the transboundary territory of neighboring states is defined.
\end{abstract}

Keywords: groundwater; aquifer; transboundary territory; UN; conventions; groundwater resource management; legal regulation; reserves

\section{Introduction}

Water is a quintessential element for the survival of mankind [1]. Groundwater occupies a special place among all types of natural resources. On the one hand, it is contained in the depths and has the main features of minerals; on the other hand, it is part of the total water resources of the planet. At the same time, groundwater has a number of features that distinguish it from other types of minerals, and which determine the fundamental differences in the formation of its operational reserves as a process that occurs not only during geological time, but directly during the development of deposits [2].

According to the first preamble of the Report of the UN International Law Commission, the international community "recognizes the importance of groundwater as a resource essential for the life of mankind. Due to rapid population growth and accelerated economic development, groundwater resources are overexploited and polluted. There is an urgent need to implement proper groundwater resource management [3]".

Speaking on the occasion of the World Water Day, on March 22, 2012, UN Secretary General Ban Ki-moon made a special appeal to all governments and all social forces of the planet to officially recognize the existence of a water crisis and do everything possible to stop this alarming trend. And this also applied to groundwater [4]. 
The administration system plays a key role in the development of the groundwater management complex. Today there is no unified water management system, which, due to its versatility and scale, "does not fit into the sphere of interests" of any of the existing ministries in Russia. According to the "Water Strategy of the Russian Federation for the Period up to 2020", the issues regarding the regulation of the use of water resources are under the jurisdiction of 14 federal executive bodies, which include more than 30 controlling bodies. As a result, the industry, which was advanced, by world standards, at the turn of the 1970s and 1980s, is not developing at the required pace [5].

The problems of domestic water industry can be conditionally divided into normativelegal, managerial, technical, financial, personnel-related, and environmental, and all of them are interconnected.

The effectiveness of the use and protection of water bodies depends not only on the state of water legislation, but also on the degree of perfection of the legislation on environmental protection, on the technical regulation in the fields of water supply and sewerage, and on the criminal and administrative liability for offenses that have a negative impact on water bodies [5], including groundwater.

To visualize the involvement of groundwater regulation issues in the legal field, it is advisable to use data from the Sustainable Development Goals, namely goal № 6-clean water and sanitation).

Many aquifers and complexes existing in the world are transboundary, that is, they lie on the territory of two or more administrative units within a country or two or more countries [6]. The object of this study is the system of state management of groundwater resources in transboundary territories. The article touches upon the problem of subsoil use during the exploitation of groundwater deposits located on the territory of neighboring states. The main goal of the paper is to improve the legal framework in the field of state regulation of groundwater extraction from transboundary territories by amending the laws governing the procedure for groundwater extraction for various purposes from transboundary aquifers and complexes. The target effect is to consolidate, at the international level, the concept of "transboundary aquifer", as well as a methodology for substantiating the width of the transboundary territory, taking into account specific geological conditions.

\section{Materials and Methods}

In the course of the study, a complex method, including the analysis and synthesis of data presented in publications of Russian and foreign authors, scientific publications of leading experts in the field of economics, hydrogeology, and ecology, reports of government hearings, reference publications of specialized institutes and agencies in the field of study, as well as an advisory method with leading foreign experts, was used. Moreover, dogmatic and comparative legal methods consisting of analyzing the applicable legal regulations on the use and protection of groundwater were also used.

In the beginning of the analysis it is important to mention its limitations. Famous documents such as the International Environmental Law (Dupuy \& Vinuales, 2016, Cambridge University Press), the Practitioner's Guide to International Law, the International Law Committee (2014, NSW Young Lawyers), etc., were not taken into account, because of the chosen object of this research-transboundary groundwater resources. As a rule, this legislation focuses mainly on surface water sources.

The authors propose to analyze the evolution of the approaches to the definition of transboundary groundwater in international agreements, conventions, and directives. Particular attention is paid to the formation of a transboundary zone and groundwater resources management issues.

The text of the 1992 Helsinki Convention defines "transboundary waters", but without differentiating between surface and groundwater sources. According to this document, transboundary water "means any surface or groundwater that crosses borders between two or more states, or is located on such borders" [7]. 
The UNECE Water Convention [8] and its obligations fully apply to transboundary groundwater. The Russian Federation shares transboundary waters with both parties to the Water Convention (of which the post-Soviet countries: Azerbaijan, Belarus, Kazakhstan, Latvia, Lithuania, Ukraine, Estonia). Along with Belarus and Tajikistan, the Russian Federation is a party to the Agreement on the basic principles of interaction in the field of rational use and protection of transboundary water bodies of the member states of the Commonwealth of Independent States (1998).

In the UN Convention "On the Law of the Non-navigational Uses of International Watercourses", which only entered into force in 2014, the subject of the regulated relations are "international watercourses", which are understood as a system of surface and ground waters that physically constitute a single whole, parts of which are in different states (New York, 1997 [9]). For a separate aquifer to fall within the scope of this Convention, it must be part of the "surface and groundwater system". From the point of view of regional hydrogeology, this approach is very incorrect, since large aquifers, complexes, and aquifer systems can be considered as belonging to different basin zonings, since their length can range from several tens to several hundred kilometers. Such large aquifers, as a rule, do not have a zone of active water exchange with surface watercourses throughout the entire area of occurrence, but have their own area of recharge and discharge.

In 2004, according to the Berlin Rules, within the Water Framework Directive of the European Union No. 2000/60/EC of 23 October, 2000 [10], definitions of aquifers appeared almost for the first time in relation to geological rocks, which are the reservoir-including the movement of groundwater, and not only to regional basins of open water bodies and watercourses [11].

It is important to note that there is no definition of transboundary groundwater in the current Russian legislation, namely in the Water Code of the Russian Federation, approved in 2006 [12], and its latest revisions. However, article 8 of the Decree of the Government of the Russian Federation of 23 May, 2001, N 405 "On signing an Agreement on cross-border cooperation in the study, development and protection of subsoil" states that "the study and development of transboundary hydrocarbon deposits and groundwater, the development of which is order will entail a change in the quantity or quality of the reserves of the part of the field belonging to the neighboring parties, should be carried out on the basis of agreements concluded between these neighboring states" [13]. It can be assumed that all existing agreements are of a framework nature and, in practical terms, will not be fully implemented. Despite the cooperation stipulated in the agreement "in the spirit of equality and partnership", each side strives to act primarily in its own interests.

At the same time, in the comments on the report of the UN International Law Commission's Sixtieth Session [3], this issue was considered, and most experts concluded that the management of transboundary aquifers should be considered independently of any work of the commission on issues related to oil and natural gas. That is, the management model of the legal regulation for the extraction of groundwater and hydrocarbon raw materials has a lot of differences.

In accordance with article 6 of the Report of the UN International Law Commission's Sixtieth Session [3], "aquifer states, when using transboundary aquifers or aquifer systems on their territory, shall take all appropriate measures to prevent significant damage other states of the aquifer or other states on whose territory the discharge zone is located". Article 7 (of the same document) notes a "cooperation based on sovereign equality, territorial integrity, sustainable development, mutual benefit, and good faith in order to achieve equitable and reasonable use and adequate protection of their transboundary aquifers or aquifer systems".

The following articles of this report concretize the main functions, the agreements of interstate agreements on the interaction of countries on the schematization of aquifers, and their systems in relation to the fields of feeding, unloading (article 11), monitoring results (article 13), development of joint management plans (article 14), unification in 
relation to the main special geological terms and parameters, and characteristics of the physicochemical properties of groundwater.

Paragraph 4 of the commentary to article 16 states that "the components of cooperation provided for in this draft article also appear in a number of conventions and treaties. For example [14] emphasizes the importance of "education and training of the professional and technical personnel needed to manage water resources, operate water systems and implement sanitation systems" and "retraining and improving their knowledge and skills".

Thus, it should be noted that the terminology used in the existing international legal instruments on transboundary groundwater is not uniform. Attempts to unify international concepts in relation to transboundary groundwater-the UN, New York and Geneva [15] were only made, for the first time, in 2014.

The same document employs the term "groundwater", while the Implementation Guide to the Convention also uses the term "aquifer", since "the Convention refers to both confined and unconfined aquifers to groundwater". In some other legal documents, the meaning of the term "aquifer" is derived from the meaning of the term "groundwater".

It is important to note that aquifers have a set of specific properties, such as filtration parameters, chemical composition, temperature, direction of the groundwater movement from the recharge area to the discharge area, filtration interaction of aquifers with each other, as well as a set of capacitive and other hydrodynamic characteristics. Geographically, aquifers or their systems cross different state boundaries, in one way or another, as noted earlier.

\section{Results}

Currently, water resources management based on the basin principle is widely used in countries with a strong centralized and decentralized power and federal structure. These states include France, Great Britain, Germany, Spain, the United States, and Austria (the Murray-Darling basin system, created in 1987). The practice of water resources management using the basin principle goes back several decades. Among the leaders in this area are the Netherlands and Germany, where it was implemented long ago and achieved significant results. It is believed that, at the state level, this principle was first implemented in Spain, where Hydrographic Confederations were formed in 1926 in 10 main basins. Over the past decade, many countries have undergone a reorganization of their water resources management systems with the aim of introducing the basin principle and increasing its efficiency. These countries also include the Republic of Kazakhstan and the Republic of Belarus [16].

State regulation in the field of water law in the Russian Federation is carried out taking into account political norms and principles of international water legislation. Currently, the Russian Federation has nine bilateral intergovernmental agreements with neighboring states on the joint use and protection of transboundary facilities and one trilateral agreement with the Republic of Abkhazia (2011), with the Republic of Azerbaijan (2010), with the Republic of Belarus (2002), with The Republic of Kazakhstan (2010), with the People's Republic of China (2008), with Mongolia (1995), with Ukraine (1992), with the Republic of Finland (1964), with the Republic of Estonia (1997), with Finland, and with the Kingdom of Norway (1959) [17].

At present, the most advanced model of basin regulation is the French one. This option is the result of the adaptation of water management structures to the centralization policy that was implemented in the early 1960s and of changes in the needs of the water sector in general.

In water resources management, the basin principle is used not only within the borders of one state, but also on an international basis. It was reflected in the 1992 Convention on the Protection and Use of Transboundary Watercourses and International Lakes, which stipulates that the riparian parties establish the boundaries of the water intake or its part(s), in respect to which they cooperate, and establish joint bodies for their development. A clear definition of the spatial boundaries of their action is of key importance in basin 
management. This requirement appears as a priority in the above-mentioned Convention on the Protection and Use of Transboundary Watercourses and International Lakes. It is also stipulated in the EU documents related to water resources management. Its implementation is important both for interstate agreements and for agreements concluded between administrative-territorial units within the state. The determination of the basin boundaries, based on hydrographic factors, can also take into account administrative-territorial divisions, economic interests, etc.

For the countries of the post-Soviet space, taking into account the state-territorial changes and the administrative and legal reforms that have taken place here, the creation of an effective water management system should have regard to international legal experience and advanced mechanisms of foreign national legislation on water resources. In 1992, Russia joined the Convention on the Protection and Use of Transboundary Watercourses and International Lakes, signed in the same year by the EU countries in Helsinki [7], and thus confirmed its orientation toward the established international practice in this area.

Nevertheless, according to the leading scientist-hydrogeologist Yazvin [2], the basin approach is largely artificial, and some of its features clearly follow the Water Framework Directive of the European Union [10]. This directive considers groundwater bodies as a part of river basins. At the same time, ground waters of deep aquifers are not distinguished as water bodies if they cannot adversely affect terrestrial ecosystems and are not suitable for drinking purposes in terms of their natural composition, as well as due to the technical or economic inexpediency of extraction.

Obviously, it is impossible to borrow directly from the European, due to the differences in the legislative framework - in particular, due to the presence in the Russian Federation of the Law "On Subsoil" [18], which regulates the issues of geological study and production of all types of groundwater in detail. Let us add, following E.N. Mukhina [19], that if, in the norms of international law, groundwater is considered, first of all, as an integral component of the natural environment, then in domestic law the legislator focuses on the natural resource approach (exploitation of groundwater).

Modern leading scientists in Russia, such as Borevsky B.V., Yazvin [20], or Abramov V.Yu., believe that groundwater should be considered exclusively as a mineral resource, and not as a free renewable resource, a definition that modern society is unfortunately used to. All the groundwater that can be used in various sectors of the economy should be considered, of course, as a mineral resource. Among the arguments in favor of this point of view, we highlight the following:

1. Groundwater is located below the surface of the earth, that is, in the earth's bowels. For this reason, its chemical composition is the result of interactions in the water-rock system and differs sharply from the composition of surface waters.

2. Groundwater, like other minerals, in the quantity and quality required for industrial development, is not widespread. The search, study, and assessment of reserves (determination of the possibility of production) is carried out by geological methods, by specialists with a geological education, based on the analysis of the hydrogeological conditions.

3. The access to the subsoil involves the use of mining and geological equipment and special technologies.

4. The use of the criterion of renewability for the separation of groundwater and mineral resources and for separation of groundwater into related and non-mineral resources is unauthorized [2].

Most analysts approach groundwater resources management only from the point of view of environmental safety, that is, in terms of pollution and depletion. This onesided approach narrows the spectrum of the problem in the field of subsoil use, since most modern research is reduced to local problems associated with technogenic factors, especially on surface water systems and aquifers located in the zone of active water exchange. The issues regarding the migration of objects that are hazardous and not always technogenic 
in regional aquifers are currently not being studied actively enough, although this is a predictive assessment of the resource potential for future generations of subsoil users.

At the same time, Model Provisions for Transboundary Groundwater [15] specify a new approach to the description of transboundary aquifers. A new factor here is the lack of direct interaction of groundwater for some aquifers with surface watercourses and water bodies within the described territory. That is, recharge and discharge areas can be located at a distance of tens to hundreds of kilometers from each other and be located on the territories of different states. In this regard, the question arises about the incorrectness of considering absolutely all aquifers by basin territorial division to solve the transboundary problem.

Undoubtedly, shallow aquifers falling into the zone of active water exchange with surface waters should be considered in the same concept with surface watercourses. But such aquifers, as a rule, have a rather limited planned distribution and are often tied to river valleys (alluvium). An example would be the Selenga river, flowing from the Mongolian Republic to Russia, in the valley of which the main water intake facilities are located. However, deep-lying aquifers have their own unique chemical composition and groundwater flow direction, which does not always coincide with the geographical location of river valleys and lake systems.

Paragraph 10 of the requirements mentions that "special agreements on groundwater could exist in the form of additional protocols to existing agreements on water concluded in accordance with Article 9 of the Water Convention, which do not mention groundwater" [15]. The authors of the text argue that aquifers should not be automatically tied, in water legislation, to a specific international river or lake basin. This leads to the important conclusion that any aquifers crossing a particular boundary should be considered transboundary, even if they are not currently being exploited.

To date, no principles have been formulated that ensure a "fair and reasonable" distribution of groundwater resources between neighboring states. In this regard, each country has its own criteria for assessing the resource potential of groundwater, as well as the prospects for development of subsoil use. In fact, hydrogeologists all over the world have long established the principles of maximum allowable drawdowns of groundwater reserves by the method of the maximum allowable lowering of the dynamic level at existing water intakes according to a coordinated monitoring system, taking into account the time tracking and the effect of one water intake on the other.

Each aquifer that is transboundary, as well as a system of aquifers, should be considered separately in international law. This means that each aquifer crossing the border must have a hydrogeological description, including the recharge and discharge areas, parameters of interaction with neighboring aquifers, hydrodynamic characteristics, parameters of resource potential, chemical and microbiological composition, including its variability, and also a parameter characterizing the direction and quantitative assessment of the natural flow, because each aquifer is primarily determined by the geological structure, its structure, strike, tectonic factors, and mineral composition.

In regional hydrogeology, this approach to geological structures and the description of aquifers is fundamental. However, in order to solve certain transboundary problems, it is necessary to identify the zone of responsibility of one or another state, since the length and depth of the study of the aquifer can be very extensive.

For example, Figure 1 shows a schematic geological section.

The crystalline rocks of the basement are shown in red in Figure 1, while the rest corresponds to the rocks of the sedimentary cover, in which the main aquifers are located. 


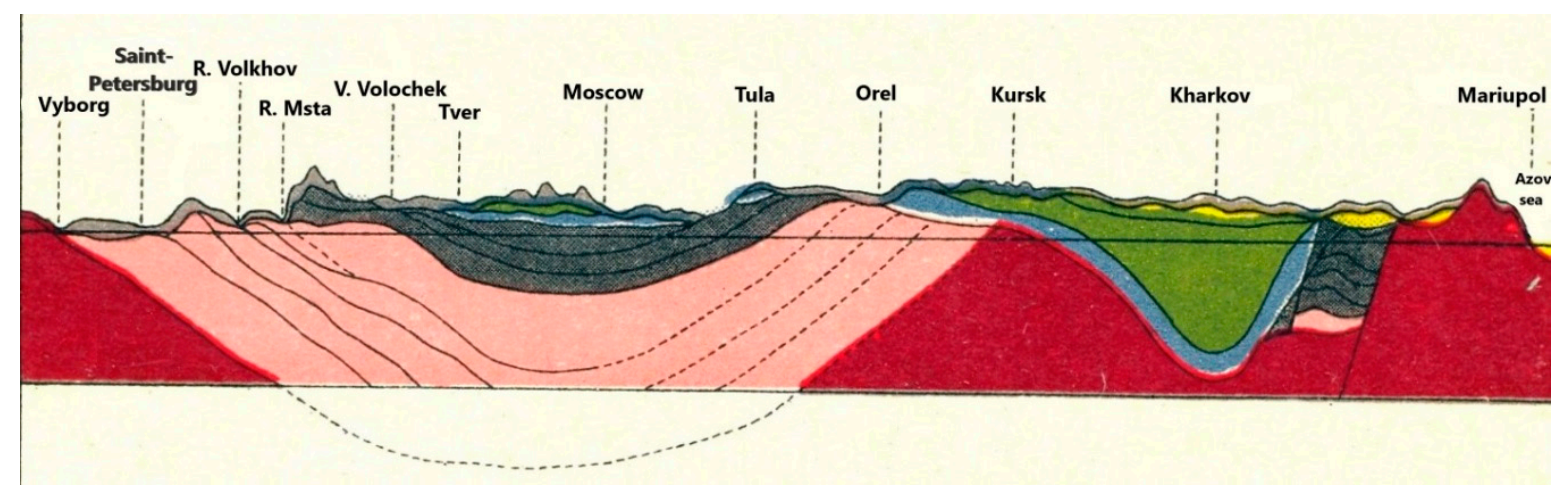

Figure 1. Schematic geological section of the European part.

\section{Discussion}

The main principle laid down in international law is to provide the population of any state with drinking water of a stable hydrochemical level, and not only for the present, but also for future generations. This is directly in line with the goals of sustainable development. In this regard, hydrogeological calculations are based on solving not only epigenous, but also predictive problems, including using numerical modeling, which in turn is based on a monitoring system responsible for high-quality initial information, as well as on a complex of hydrogeological studies as at the exploratory stage and in the exploration of groundwater deposits.

Model Provisions for Transboundary Groundwater [15] sharply raise the question of establishing the boundaries and general parameters of transboundary aquifers. In this regard, when developing a joint interstate groundwater monitoring program, questions arise on the unification of standards and methods for conducting monitoring studies and criteria for assessing the aquifer parameters, creating and updating geological and hydrogeological regional maps, which can form the foundation of a mathematical model and methods of transboundary resource regulation. Appendix II to the EU Water Framework Directive [10] provides specific guidance on the parameters to be taken into account in the process of characterizing groundwater bodies (page 8), but in a very abbreviated form.

In accordance with Regulation 4 of [15], states cooperate in the integrated management of their transboundary ground and surface waters. There are many examples of such cooperation. A positive example is the regulation of the Franco-Swiss Geneva Aquifer (1978 Convention), the 1994 Israel-Jordan Peace Treaty, the 1973 American-Mexican International Commission on Frontiers and Waters, whereby the parties clearly agreed to limit the abstraction of groundwater to a specific geographic region.

More detailed information on conflicts in the field of transboundary regulation of groundwater extraction is presented in Table 1.

Conflicts in the use of groundwater, despite not being frequently mentioned in the literature, exist, and their number may increase in the future due to a number of factors, such as an increase in demand for groundwater use, insufficient monitoring, inefficiency of structures and institutions for water resources management-in particular, weak policies, laws and regulations-and insufficient administrative capacity at the local level. Other factors include fragmented planning and management, lack of integrated approaches, climate change, conflicting industry policies, rapid population growth and economic development. Several authors, such as [22], argue that the causes of conflicts in groundwater use vary depending on circumstances such as dry wells, water pollution, and reduced base flow. This suggests that there is a need for well-functioning and strengthened structural and institutional mechanisms at the local, national, and international levels to resolve conflicts related to groundwater. 
Table 1. International conflicts in the field of transboundary regulation of groundwater extraction.

\begin{tabular}{c}
\hline Geography \\
\hline $\begin{array}{c}\text { Argentina, Brazil, Paraguay, and } \\
\text { Uruguay; Guarani aquifer }\end{array}$
\end{tabular}

Uruguay; Guarani aquifer

Pollution and overexploitation of resources, in the context of increasing water demand in the region

Germany, Netherlands, Garzweiler district

Impact of mining on groundwater levels

Solution

Institutional cooperation between countries: a Strategic Action Plan for 2003-2009 was developed.

As part of the agreement signed in 2010, it is

planned that a regional committee for the Guarani

Aquifer System will be established within the La

Plata International Coordinating Committee, under the auspices of the 1969 La Plata Basin Treaty.

Country cooperation: experts from the

Netherlands participated in the preparation of the environmental impact assessment reports, while the public was informed about the results of the respective monitoring programs.

Construction of an artificial replenishment station; Signing of the agreement between the Canton of Geneva and the Prefecture of Haute-Savoie in 1978, its extension in 2007-2008. Creation of a

France, Switzerland, Geneva aquifer Excessive production and, as a result, the depletion of the aquifer

Franco-Swiss working group to develop a baseline document covering the Geneva Aquifer for the next 30 years.

1973 American-Mexican International Commission on Frontiers and Waters, whereby the Parties agreed to limit groundwater abstractions in a well-defined geographic region along the

USA, Mexico Lack of regulated water intake limits

Arizona-Sonora border to specially set abstraction targets. To avoid future problems, the United States and Mexico will consult with each other before taking any measures to develop surface or groundwater resources or introduce any significant changes to the existing situation in the border area that could negatively impact another country.

\begin{tabular}{|c|c|c|}
\hline $\begin{array}{l}\text { Kazakhstan, Uzbekistan, } \\
\text { Pritashkent aquifer }\end{array}$ & $\begin{array}{l}\text { A decrease in the level of groundwater due to } \\
\text { intensive exploitation, which leads to the problem } \\
\text { of the depletion of its reserves, as well as a } \\
\text { potential problem of deterioration of the quality of } \\
\text { groundwater. }\end{array}$ & \multirow{3}{*}{$\begin{array}{c}\text { There is no solution to this problem yet, it is } \\
\text { included in the GGRETA program [21]. The aim of } \\
\text { the GGRETA project ("Management of } \\
\text { groundwater resources in transboundary } \\
\text { aquifers") is to build on relevant experience } \\
\text { through three pilot studies of transboundary } \\
\text { aquifer systems }\end{array}$} \\
\hline $\begin{array}{c}\text { Guatemala, Honduras, El Salvador, } \\
\text { Esquipulas-Ocotekue-Kitala } \\
\text { (Trifinio) aquifer }\end{array}$ & Aquifer pollution & \\
\hline $\begin{array}{l}\text { Namibia, Botswana, South Africa, } \\
\text { Kalahari Karu (Stampriet) aquifer }\end{array}$ & $\begin{array}{l}\text { There is no serious pressure on groundwater } \\
\text { reserves, which may be due to insufficient } \\
\text { monitoring, but the extremely low level of } \\
\text { groundwater abstraction undoubtedly also plays } \\
\text { an important role. If for some reason (population } \\
\text { growth, economic development, etc.) there is a } \\
\text { significant increase in water demand in a given } \\
\text { region, groundwater resources will very quickly } \\
\text { cease to meet the needs. }\end{array}$ & \\
\hline $\begin{array}{l}\text { Israel, Palestine, mountainous and } \\
\text { coastal aquifers }\end{array}$ & $\begin{array}{l}\text { Water apartheid, i.e., Israeli control of } \\
\text { transboundary aquifers }\end{array}$ & $\begin{array}{l}\text { The lack of a solution to this problem } \\
\text { at the moment }\end{array}$ \\
\hline
\end{tabular}

The concept of conflict is very clearly defined in the literature as a disagreement or misunderstanding within, between, or between individuals, groups, and governance structures that escalate into violent actions, including physical struggle [23]. A misunderstanding becomes a conflict when it has a serious impact on the parties involved due to poorly managed changes in policy, the legal or institutional context, and political, economic, and social changes. Using this approach, such conflicts become groundwater use conflicts if they arise between groundwater users, or between the management structures responsible for groundwater management. Resolving groundwater conflicts requires an adequate technical understanding of the parties involved, the causes and governance structures, and the institutions that are critical to resolving them. 
Judging by the events of 2012 on the borders of Syria with Turkey and Lebanon, the link between civil conflict and lack of groundwater is a close one. Moreover, these conflicts can affect several states. Local conflicts are invariably driven by governance (or a lack thereof), poverty, and instability, often with the leverage of opportunistic insurgent organizations, and water scarcity is often a key factor in such instability.

The management of all groundwater is necessary to achieve the goal of sustainable supply. To achieve this, and indeed to make any properly informed groundwater management decision, resources must be monitored regularly [24]. The collected data can then be used to construct and validate groundwater runoff models, allowing different "what-if" scenarios to be formulated, and to provide policymakers with important insights into the likely productivity of their local aquifer. However, in many poorer countries, monitoring is often inadequate or even lacking, making it impossible to conduct validated simulations. It is these countries that are most at risk of misuse of groundwater sources and where the likelihood of stopping groundwater inflows is greatest.

In accordance with Regulation 5 of the Model Provisions for Transboundary Groundwater [15], "the parties shall take appropriate measures to prevent, control and reduce pollution of transboundary groundwater, especially those intended for drinking water supply". In this regard, they follow the precautionary principle in view of the vulnerability of groundwater to pollution, especially in cases of possible uncertainty about the nature and extent of transboundary groundwater. For this, it is proposed:

- to pay attention not only to the aquifer recharge area to prevent possible sources of pollution, but also throughout virtually the entire aquifer up to the discharge area;

- to harmonize, at the international level, the standards for the quality of drinking groundwater in connection with the difference in the approach to the concentration of microcomponents contained in groundwater in different states. This is especially typical for areas with an acute shortage of groundwater resources and regions with a high instability in the chemical composition of groundwater associated with the geological structure of aquifers-for example, tectonically active zones.

- to minimize the threat of the depletion of groundwater resources when mining enterprises conduct drainage activities (mine and quarry drainage);

- to refrain from using risky technologies (for example, shale oil extraction, disposal of hazardous toxic waste in the structure of an underground reservoir) in those regions where the existence of transboundary aquifers has been proven.

Within the framework of the international management system for transboundary groundwater resources, it is necessary, first of all, to create a unified information field on the state and use of transboundary groundwater. Countries should develop and implement joint or agreed plans for the proper management of their transboundary groundwater. One of the areas of such a plan is the prescription of withdrawal limits, inter alia, in the form of quantifying the total annual withdrawal and criteria for the placement of new wells and the development of other water withdrawals.

The principle of integrated management used for the basin approach can only be applied to aquifers that have a zone of active water exchange with surface water bodies and watercourses. As a rule, such horizons include waters of alluvial river sediments, groundwater, shallow unconfined aquifers, underground waters of karst structures, as well as local aquifers with small geometrical dimensions and thickness [25-27].

In the Model Provisions for Transboundary Groundwater [15] "to implement the goals and principles of these Model Provisions and coordinate their cooperation in the management of transboundary aquifers, the states may establish a joint body", performing the functions of coordinating actions to prevent conflict situations in the field of border subsoil use.

Transboundary regulation of groundwater extraction and use implies the following basic provisions: 
1. A perfect and unified structure of the state regulation in the field of subsoil use in the territories of border states, including:

- a licensing system for geological exploration and groundwater extraction,

- monitoring based on the systematic observation of the development of groundwater deposits,

- a program of exploration work in order to study the structure, hydrogeological parameters, and variability of the chemical composition of groundwater,

- assessment and reassessment of groundwater reserves to a higher category, which increases the degree of reliability of the initial information,

- a developed scientific and design base that allows for analytical research, building predictive models, and designing and optimizing promising water intakes.

2. The size of the transboundary zone should have certain parameters, since without solving this problem it is impossible to determine the zone of responsibility of the states in the joint development of aquifers or complexes.

As mentioned earlier, most experts, not only in Russia but also abroad, consider transboundary aquifers in the context of global geological structures [28-34].

Often, such geological structures have an area commensurate with the area of an average European state, and the approach to their problems includes research on areas of recharge, discharge, direction of groundwater flow, interaction with neighboring horizons, surface water bodies and watercourses, as well as boundary conditions of various kinds. This global approach typically ranks major aquifers by basin location. From the point of view of global regional hydrogeology, this is absolutely true; however, it is completely unrealistic for solving the problems of managing transboundary aquifers, because the problem of legislative and managerial tasks has a very limited scale. That is, it proposes to consider the transboundary territory from the standpoint of areas of responsibility.

The transboundary territory should have a certain limitation on the area of distribution, which is determined by hydrogeological parameters and characteristics. It is to this territory that the relevant rules and regulations can be applied. According to preliminary calculations, the width of the transboundary aquifer can range from a few kilometers to a few dozens of kilometers.

Previously, the authors developed a methodology for managing groundwater production in the territory of the transboundary zone, determined the sizes, parameters, and factors affecting its formation (using the example of the research and analysis of water intake activities in the border territories of the Russian Federation and the Republic of Estonia). According to the results of hydrogeological calculations, the width of the transboundary territory for this example was $47 \mathrm{~km} \mathrm{[6].} \mathrm{This} \mathrm{area} \mathrm{requires} \mathrm{a} \mathrm{special} \mathrm{en-}$ vironmentally balanced subsoil use regime. From the calculations, it can be concluded that, inevitably, in the territory of one of the states, the volume of water resource extraction will always be higher than in the territory of a neighboring country. A quantitative assessment of the water resources taken from the aquifer of a neighboring state can be performed by calculation using the balance method. To date, the quantitative indicators of the extracted resources cannot have a monetary equivalent as a commercial product; therefore, mutual settlements between states exploiting the same aquifer cannot be carried out in value terms. The factors limiting the excessive extraction of groundwater from transboundary aquifers should be the criteria for the position of the groundwater level, as well as for their quality within the framework of the interstate agreements reached, which are monitored within the framework of the international groundwater monitoring system. Such hydrogeological calculations can be carried out for any other conditions and areas. Of particular importance is the presence of mining enterprises and hydraulic structures, as well as the extraction of shale oil in cross-border areas. In future studies, we plan to expand the geography of the aquifers selected for analysis, lying on the border territory of Russia and its neighboring countries. 
Such an approach, according to the authors' concept, can form the basis for the development of international rules and laws for the management of the resource potential of groundwater in transboundary territories.

At present, unfortunately, the Ministry of Natural Resources and Ecology of Russia plays the role of a purely controlling agency, and only within certain limits. The adoption of the modern version of the Law of the Russian Federation "On Subsoil" made it possible to abandon the assessment of reserves for low-flow water intakes (up to $100 \mathrm{~m}^{3}$ /day), which led, in turn, to an uncontrolled process of groundwater extraction over vast territories. Many single collective water intakes (for example, in dacha settlements) receive licenses for just such volumes of production. In this context, the concept of assessing reserves loses all meaning; such objects simply do not fall into the annual monitoring reports. This is where the problem of groundwater resources management arises, and, consequently, the construction of forecast calculations will lead to serious errors. Technically, the procedure for assessing reserves requires certain qualifications and knowledge, but in the old days, any hydrogeologist could cope with this task.

After the commissioning of a water intake facility, state committees practically do not control its activities, except for sanitary standards. This was the essential task of the Ministry of Geology in the USSR. The specific features of adjacent subsoil use within the transboundary zone are a complete absolute control and the planning of all water intake facilities from the transboundary zone to the territory of responsibility of a neighboring state. It is also necessary to have a special cross-sectional monitoring regime, implying a two-way system of observation points (wells), the location of which is determined by the parameters of the aquifer or complex, as well as the degree of loading during the exploitation of the aquifer or the presence of mining enterprises, whose activities include mining drainage. Such objects in the transboundary zone usually have an additional pressure on the groundwater aquifer system, both in terms of the depletion of reserves and the potential change in the chemical composition of groundwater.

In the modern methodology for licensing water intakes, when assessing reserves in the border area, the impact of water intake activities on underground water intake facilities on both sides of the state border is not taken into account at all. It is advisable to use the hydrodynamic calculation scheme as a type II boundary, that is,

$$
\mathrm{Q}=0
$$

where $Q$ is the amount of water inflow at the border of two media ( $\mathrm{m}^{3} /$ day).

Schematization is possible on the division of two state territories for calculating water inflows to underground water intakes, and, accordingly, maximum level decreases for the calculation period. This approach can be applied at the present stage before the adoption of international methods for the management of transboundary waters.

The hydrodynamic diagram in Figure 2 characterizes one of the possible approaches for calculating the water inflow to a water intake structure located in the transboundary zone of influence of a neighboring state. The calculation models conditionally characterize the quantitative water influx from the territory of a neighboring state, equal to zero, that is, the advisability of using such a scheme is due to the lack of information on the hydrodynamic characteristics of the exploited aquifer in the adjacent territory. 


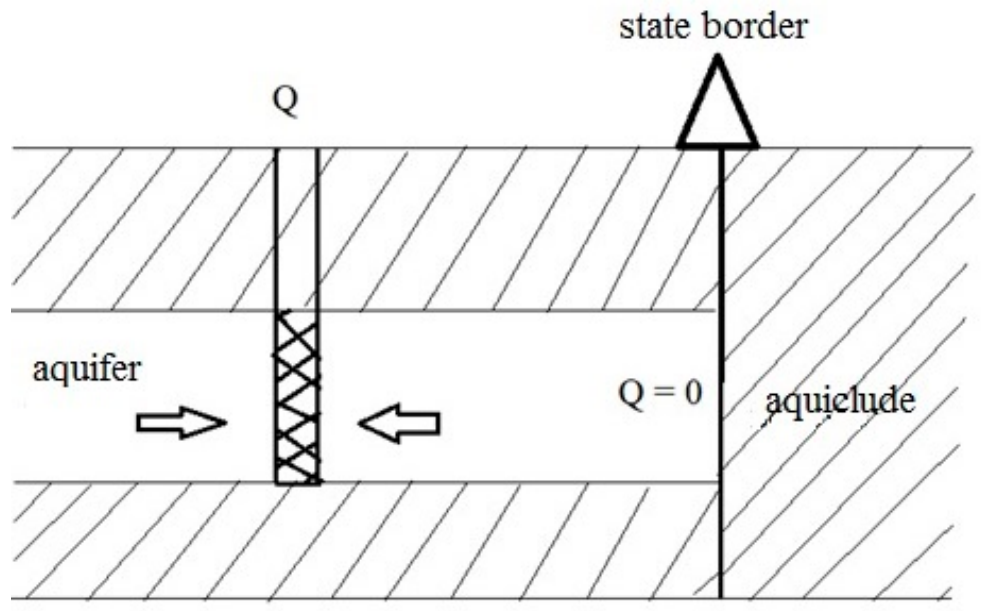

Figure 2. Hydrodynamic diagram.

\section{Conclusions}

Within the framework of the article, specific tasks for the study and use of transboundary aquifers were identified. The authors propose to calculate the so-called zone of responsibility (transboundary territory) during the operation of groundwater intakes on the basis of the basic hydrodynamic parameters of the main aquifers, but subject to their detailed study, even if the aquifers are not currently used for groundwater extraction. To deal with the international system for transboundary groundwater resources management, it is necessary, first of all, to create a unified information field on the state and use of transboundary groundwater.

At present, the following specific tasks concerning the study and use of transboundary aquifers can be identified:

- the quantitative assessment of natural and operational resources of boundary and transboundary aquifers;

- the determination of the chemical, biological, and radionuclide composition of groundwater and the permissible level of their changes;

- the assessment of the vulnerability of the fresh groundwater of transboundary aquifers to technogenic pollution from the earth's surface;

- the scientific and methodological substantiation of interstate agreements on the permissible limits for the use of groundwater in transboundary aquifers, including, first of all, geoecological aspects, permissible levels of groundwater withdrawal, the risk of pollution, and the depletion of aquifers;

- the development of joint interstate monitoring of the use and protection of groundwater in transboundary aquifers.

According to I.S. Zektser [35], when determining the prospects for the use of groundwater and the management of water intake facilities, factors of limitation of the operation arise in connection with various criteria. These include the limitation associated with geological and hydrodynamic operating conditions: the amount of groundwater recharge, the maximum permissible decrease in the dynamic level, as well as the danger of pulling up groundwater from adjacent aquifers. All these criteria are associated, as a rule, with the complex structure of aquifers and their systems, the study of which must be carried out in the transboundary territory.

Zektser I.S. [34] notes that the issues of groundwater resources management in border areas-in hydrogeological, socio-legal, and in economic aspects-are practically not worked out. Among the main tasks are:

1. the determination of permissible limits for the withdrawal of groundwater from a transboundary aquifer;

2. the regional assessment of the natural groundwater resources of the exploited aquifer; 
3. the assessment of the likelihood of pollution of the transboundary aquifer during their joint exploitation.

The main task of groundwater resources management in the transboundary territory is the allocation of the zone of responsibility of neighboring states, within which a special regime of subsoil use is implied. The authors propose to calculate the so-called zone of responsibility (transboundary territory) during the operation of underground water intakes on the basis of the hydrodynamic parameters of the main aquifers. In international practice, several models for managing transboundary mineral deposits are used. The main types of interaction are based on interstate bilateral treaties that define very general principles and management tasks [36,37]. As a rule, this concerns issues of pollution, ecology, surface watercourses, and water bodies. At the same time, these agreements are ineffective for solving specific problems.

In the world practice of joint exploitation of oil and gas fields, a model of unitization has been developed and successfully applied in transboundary fields [38-40]. The main types of management tasks are based on the functions of state control from neighboring countries, but the unit models themselves have a number of differences. Nevertheless, there is a common aspect-the definition of the boundaries of the exploited field, and hence the boundaries of responsibility and interests. Each mining company within a unitization zone is subject to a unitization agreement. This is a significant difference from the development of groundwater deposits: since the area of responsibility at the interstate level for the transboundary territory has not yet been determined in world practice, there are no unified mechanisms for its assessment. The second difference is that an unlimited number of subsoil users (legal entities and individuals) can be located on the border territory, whose activities cannot be united by a unitization agreement.

However, the principle of the licensing of the subsoil use remains in the jurisdiction of the state, that is, the management of the development of groundwater deposits is assumed by the state apparatus that issues the license. Today, when issuing and registering licenses for groundwater extraction, the impact of water intake on water use facilities located outside the state border is not at all taken into account. In this regard, clearly fixed conditions for the development of transboundary groundwater deposits are required.

At first glance, the task of managing transboundary aquifers seems very complex and ambiguous, but modern society is approaching a stage where it needs to resolve this problem as soon as possible. The modern hydrogeological community, based on the richest world experience in solving such problems, is quite ready to implement an innovative approach to the adoption of general principles and international legislation in the field of groundwater extraction in transboundary territories on an international scale.

Author Contributions: Conceptualization, E.G.; methodology, E.G.; software, E.G. and K.K.; validation, E.G. and K.K.; formal analysis, E.G.; investigation, E.G. and K.K.; resources, E.G.; data curation, E.G.; writing —original draft preparation, E.G. and K.K.; writing—review and editing, E.G.; visualization, E.G.; supervision, E.G.; project administration, E.G.; funding acquisition, E.G. All authors have read and agreed to the published version of the manuscript.

Funding: This research is supported by a grant from the President of the Russian Federation (project no. MK-5940.2021.2, “Development of an international system for the management of groundwater resources in transboundary territories").

Institutional Review Board Statement: Not applicable.

Informed Consent Statement: Not applicable.

Data Availability Statement: Not applicable.

Conflicts of Interest: The authors declare no conflict of interest. 


\section{References}

1. Hong, W.J.; Shamsuddin, N.; Abas, E.; Apong, R.A.; Masri, Z.; Suhaimi, H.; Gödeke, S.H.; Noh, M.N.A. Water Quality Monitoring with Arduino Based Sensors. Environments 2021, 8, 6. [CrossRef]

2. Yazvin, A.L. Once again about "underground waters and minerals". Explor. Prot. Min. Res. 2020, 5, 7-12.

3. Report of the International Law Commission Sixtieth Session (5 May-6 June and 7 July-8 August 2008). UN General Assembly. Supplement No. 10 (A/63/10). Available online: https://www.un.org/ru/documents/decl_conv/conventions/pdf/intorg_ responsibility.pdf (accessed on 2 June 2021).

4. Message on the Occasion of World Water Day. 22 March 2012. Available online: https://www.un.org/ru/sg/messages/2012 / waterday.shtml (accessed on 2 June 2021).

5. Karlov, G.A. Water Resources Management in Russia. Legislative Regulation and Prospects; Publication of the State Duma: Moscow, Russia, 2014; 192p. Available online: http:/ / duma.gov.ru/media/files/XYYU3ZZBG25w79obF7jabDefcL0Et974.pdf (accessed on 10 May 2021).

6. Golovina, E.I.; Grebneva, A.V. Some Aspects of Groundwater Resources Management in Transboundary Areas. J. Ecol. Eng. 2021, 22, 106-118. [CrossRef]

7. UNECE Convention on the Protection and Use of Transboundary Watercourses and International Lakes, Helsinki. 1992. Available online: https:/ / treaties.un.org/doc/Treaties/1992/03/19920317\%2005-46\%20AM/Ch_XXVII_05p.pdf (accessed on 8 June 2021).

8. UNECE Water Convention. Implementation Guide. New York and Geneva. 2013. Available online: https://unece.org/fileadmin/ DAM/env/water/publications/WAT_Guide_to_implementing_Convention/ECE_Water_Guide_Rus_WEB.pdf (accessed on 8 June 2021).

9. UN Convention "On the Law of the Non-Navigational Uses of International Watercourses", New York. 1997. Available online: https:/ / www.un.org/ru/documents/decl_conv/conventions/watercrs.shtml (accessed on 8 June 2021).

10. Water Framework Directive 2000/60/EU. 23 October 2000. Available online: http://caresd.net/iwrm/new / doc/direct.pdf (accessed on 8 June 2021).

11. Greco, M.; Arbia, F.; Giampietro, R. Definition of Ecological Flow Using IHA and IARI as an Operative Procedure for Water Management. Environments 2021, 8, 77. [CrossRef]

12. Water Code of the Russian Federation. Available online: http:/ /www.cabri-volga.org/DOC/PolicyRoundtable/WaterCodeOfRFUnofficialEnglishTranslation.pdf (accessed on 10 June 2021).

13. Decree of the Government of the Russian Federation of 23 May 2001 N 405 “On the Signing of an Agreement on Cross-Border Cooperation in the Study, Development and Protection of Mineral Resources". Available online: https://base.garant.ru/1155621/ (accessed on 10 June 2021).

14. Protocol on Water and Health and the 2030. UN, Geneva. 2019. Available online: https://unece.org/DAM/env/water/ publications/WH_16_SDG_Guide/ECE_MP.WH_16_RUS_web.pdf (accessed on 13 June 2021).

15. Model Provisions for Transboundary Groundwaters. UN, New York and Geneva. 2014. Available online: https://unece.org/ DAM/env/water/publications/WAT_model_provisions/ece_mp.wat_40_eng.pdf (accessed on 15 June 2021).

16. Kashirin, V.V. The Right to Water. In Water Resources Management in Russian Legal Regulation and Prospect; Publication of the State Duma: Moscow, Russia, 2014; pp. 14-33.

17. Bolgov, M.V.; Demin, A.P.; Shatalova, K.Y. International Cooperation of Russia in the Use and Protection of Transboundary Water Facilities: Experience and Problems. In Water Resources Management in Russian Legal Regulation and Prospect; Publication of the State Duma: Moscow, Russia, 2014; p. 35.

18. Law of the Russian Federation on Subsoil, February 21, 1992, N 2395-1. Available online: http:/ /www.consultant.ru/document/ cons_doc_LAW_343/ (accessed on 13 June 2021).

19. Mukhina, E.N. Groundwater as an object of legal regulation of branches of natural resource law. J. Rus. Law 2010, 9, 99-105.

20. Borevky, B.V.; Yazvin, A.L. Classification of groundwater useful reserves and undiscovered resources: History of creation from middle 20th to early 21st century. The way made. Subsoil. Use XXI Cent 2020, 2, 48-59.

21. Management of Groundwater Resources from Transboundary Aquifers (GGRETA Project); UNESCO: London, UK, 2015. Available online: https: / / www.un-igrac.org/file/1206/download?token=2qFv-B9r (accessed on 17 June 2021).

22. Tuinhof, A.; Foster, S.; Kemper, K. Sustainable Groundwater Management: Concepts and Tools; World Bank (GWMATE): Wallingford, UK, 2011.

23. Kweka-Msale, C.; Magina, F. Conflict Management in Rural Water Sources. 2009. Available online: https://www.fig.net/ resources/proceedings/fig_proceedings/fig2009/papers/ts02d/ts02d_kwekamsale_magina_3433.pdf (accessed on 15 June 2021).

24. Taylor, C.; Alley, W. Ground-Water-Level Monitoring and the Importance of Long-Term Water-Level Data; U.S. Geological Survey: Denver, CO, USA, 2001.

25. Dvoynikov, M.V.; Kuchin, V.N.; Mintzaev, M.S. Development of viscoelastic systems and technologies for isolating water-bearing horizons with abnormal formation pressures during oil and gas wells drilling. J. Min. Inst. 2021, 247, 57-65. [CrossRef]

26. Stroykov, G.A.; Ilyinova, A.A.; Romasheva, N.V. Prospects and social effects of projects for sequestration and use of carbon dioxide. J. Min. Inst. 2020, 244, 493-502.

27. Mironova, A.V.; Molsky, E.V.; Rumanin, V.G. Transboundary problems in the exploitation of groundwater in the region of the state border of Russia-Estonia (on the example of the Lomonosov-Voronkovsky aquifer). Wat. Res. 2006, 33, 423-432. 
28. Kuchin, A.G. Typification of Transboundary Groundwater Bodies in Kazakhstan. Available online: http://nblib.library.kz/elib/ library.kz/journal/Kushin.pdf (accessed on 28 June 2021).

29. Lange, I.U.; Lebedeva, J.A. Engineering-geological zoning of the route of technological tunnel designed under complex structural and tectonic conditions. Int. J. Civ. Eng. Technol. 2019, 10, 1496-1505.

30. Lange, I.Y.; Lebedeva, Y.A.; Kotiukov, P.V. A Study of Water Permeability of Coal Ash and Slag to Assess the Possibility of Their Use as Road Pavement Layers. Int. J. Civ. Eng. Technol. 2020, 2, 374-378. [CrossRef]

31. Danilov-Danilyan, V.I.; Khranovich, I.L. Water resources management. Harmonization of water use strategies. Sci. World 2010. Available online: http:/ / www.cawater-info.net/review/pdf/russia_wm3.pdf (accessed on 28 June 2021).

32. Dashko, R.E.; Kotiukov, P.V. Fractured clay rocks as a surrounding medium of underground structures: The features of geotechnical and hydrogeological assessment. Geomech. Rock Mass 2018, 1, 241-248.

33. Zektser, I.S. Main directions of researching transboundary aquifers in determining operation prospects. In Proceedings of the Higher Educational Institutions Geology and Exploration, Sergo Ordshonikidze University, Moskva, Russia, 7 January 2007; Volume 6, pp. 64-67.

34. Zektser, I.S. Investigation of transboundary aquifers in Russia: Modern state and main tasks. NATO Sci. Peace Secur. Ser. C Environ. Secur. 2012, 129, 79-85.

35. Smirnova, N.V.; Cherepovitsyn, A.E.; Ilinova, A.A. Application of Norwegian and Russian legislative basis during collaborative development of transboundary hydrocarbon fields. Eur. Res. Stud.J. 2018, 21, 434-441.

36. Litvinenko, V.S. Digital Economy as a Factor in the Technological Development of the Mineral Sector. Nat. Resour. Res. 2019, 28, 1521-1541. [CrossRef]

37. Pavlovich, A.A. Korshunov, V.A.; Bazhukov, A.A.; Melnikov, N.Y. Estimation of Rock Mass Strength in Open-Pit Mining. J. Min. Inst. 2019, 244, 502-509. [CrossRef]

38. Cherepovitsyn, A.E.; Arild, M.; Smirnova, N.V. Development of Transboundary Hydrocarbon Fields: Legal and Economic Aspects. Ind. J. Sci. Tech. 2016, 9, 107527. [CrossRef]

39. Cherepovitsyn, A.E.; Ilinova, A.A.; Romasheva, N.V. Unitization mechanisms in developing hydrocarbon deposits in the context of the interests of key stakeholders. Russ. Econ. Int. J. 2017, 4, 71-93.

40. STRATIGRAPHY. Subdivisions of Sedimentary Strata of the Earth's Crust for the Central Part of the European Territory of Russia. Available online: http:/ / www.bibliotekar.ru/2-7-32-geologiya-podmoskoviya/3.htm (accessed on 28 June 2021). 